\title{
Apigenin inhibits growth and induces apoptosis in human cholangiocarcinoma cells
}

\author{
PANTIPA SUBHASITANONT ${ }^{1}$, DARANEE CHOKCHAICHAMNANKIT ${ }^{1}$, KHAJEELAK CHIABLAEM $^{1}$, \\ SIRIPORN KEERATICHAMROEN ${ }^{1}$, LUKANA NGIWSARA ${ }^{1}$, N. MONIQUE PARICHARTTANAKUL ${ }^{1}$, \\ KRIENGSAK LIRDPRAPAMONGKOL ${ }^{1}$, CHURAT WEERAPHAN $^{1}$, \\ JISNUSON SVASTI $^{1,2}$ and CHANTRAGAN SRISOMSAP ${ }^{1}$
}

${ }^{1}$ Laboratory of Biochemistry, Chulabhorn Research Institute; ${ }^{2}$ Applied Biological Sciences Program, Chulabhorn Graduate Institute, Bangkok 10210, Thailand

Received April 26, 2016; Accepted February 1, 2017

DOI: $10.3892 / 01.2017 .6705$

\begin{abstract}
A promising nutraceutical, apigenin, was recently revealed to exhibit biological activity in inhibiting several types of cancer. The effects of apigenin on the growth inhibition and apoptosis of the cholangiocarcinoma HuCCA-1 cell line were investigated. Protein alterations subsequent to apigenin treatment were studied using a proteomic approach. The values of 20, 50 and $90 \%$ inhibition of cell growth $\left(\mathrm{IC}_{20}, \mathrm{IC}_{50}\right.$ and $\mathrm{IC}_{90}$ ) were determined by MTT cell viability assay. Apoptotic cell death was detected using two different methods, a flow cytometric analysis (Muse Cell Analyzer) and DNA fragmentation assay. A number of conditions including attached and detached cells were selected to perform two-dimensional gel electrophoresis (2-DE) to study the alterations in the expression levels of treated and untreated proteins and identified by liquid chromatography (LC)/tandem mass spectrometry (MS/MS). The $\mathrm{IC}_{20}, \mathrm{IC}_{50}$ and $\mathrm{IC}_{90}$ values of apigenin after $48 \mathrm{~h}$ treatment in HuCCA-1 cells were 25, 75 and $200 \mu \mathrm{M}$, respectively, indicating the cytotoxicity of this compound. Apigenin induced cell death in HuCCA-1 cells via apoptosis as detected by flow cytometric analysis and exhibited, as confirmed with DNA fragmentation, characteristics of apoptotic cells. A total of 67 proteins with altered expression were identified from the 2-DE analysis and LC/MS/MS. The cleavage of proteins involved in cytoskeletal, cytokeratin 8, 18 and 19, and high expression of S100-A6 and S100-A11 suggested that apoptosis was induced by apigenin via the caspase-dependent pathway. Notably, two proteins, heterogeneous nuclear ribonucleoprotein $\mathrm{H}$ and $\mathrm{A} 2 / \mathrm{B} 1$, disappeared completely subsequent to treatment, suggesting the role of apigenin in inducing cell death. The present study indicated that apigenin demonstrates
\end{abstract}

Correspondence to: Dr Chantragan Srisomsap, Laboratory of Biochemistry, Chulabhorn Research Institute, 54 Kamphaeng Phet 6 , Talat Bang Khen, Bangkok 10210, Thailand

E-mail: chantragan@cri.or.th

Key words: apigenin, cholangiocarcinoma, apoptosis, proteomics an induction of growth inhibition and apoptosis in cholangiocarcinoma cells and the apoptosis pathway was confirmed by proteomic analysis.

\section{Introduction}

A nutraceutical is a food or a part of a food that provides medicinal and health benefits (1). Several nutraceuticals originate from natural sources. Understanding the action of these active nutritional compounds and their mechanisms associated with their health benefits is of interest. Apigenin, 4',5,7-trihydroxyflavone, is a promising food-based flavonoid compound present abundantly in common fruits and vegetables including oranges, parsley, celery, spearmint, tea, wheat sprouts, perennial chamomile, onions and a number of seasonings (2). It has been demonstrated to display a variety of biological activities, including anti-inflammatory, anti-oxidant, anticarcinogenic, chemoprevention and tumor growth inhibition $(3,4)$.

The higher incidence of cholangiocarcinoma (CCA), a malignant tumor derived from intrahepatic or extrahepatic biliary tracts, occurs in Southeast Asian countries such as Thailand (5). Congenital liver malformations, primary sclerosing cholangitis and infection with the parasitic liver flukes Opisthorchis viverrini are risk factors for cholangiocarcinoma (6). The risk of cholangiocarcinoma increases in patients with chronic liver disease with either form of viral hepatitis, $\mathrm{B}$ or $\mathrm{C}(7,8)$, alcoholic liver disease or cirrhosis from a number of causes $(9,10)$. Our group has established the proteomic map of a Thai human cholangiocarcinoma HuCCA-1 cell line and compared it to Thai human hepatocellular carcinoma HCC-S102 cell line and hepatoblastoma HepG2 cell line by studying their soluble proteins (11) and membrane proteins (12).

Apoptosis, a process of programmed cell death in multicellular organisms, is one of the main types of cell death pathway and involves a series of biochemical events, which lead to cell morphology and mortality (13). When the apoptotic process occurs, the cell body and fragments are safely disposed. This serves a critical role in the multiple steps of tumorigenesis. The specific proteolytic activities of caspases, cysteinyl-aspartate proteases, are recognized to be responsible for many of these 
morphologic alterations $(14,15)$. Several proteins are known to potentially inhibit (16) or promote (17) the onset of apoptosis by a number of means of activation. Several studies have focused on apoptosis-associated proteins in apoptotic cells $(18,19)$.

The use of apigenin as an anticancer agent in vitro for the treatment of various cancer cells including prostate, breast, cervical, lung, tongue oral, leukemia and colorectal cancer has increased (20-22). The evidence of apigenin-induced apoptosis has been demonstrated in a number of cancer cell lines but there is no study on the anticancer action of apigenin on cholangiocarcinoma cell lines.

In the present study, MTT assays were performed to study the cytotoxicity of apigenin on a cholangiocarcinoma cell line, and flow cytometric analysis was employed to determine the induction of apoptosis. The proteomic analysis was also used to study the differential protein expression between apigenin-treated and untreated cells.

\section{Materials and methods}

Cell culture. The HuCCA-1 cell line, derived from a bile duct tumor mass, was provided by Professor Stitaya Sirisinha, Faculty of Science, Mahidol University (Bangkok, Thailand) and grown as a monolayer culture in Ham's F12 culture medium (Gibco Life Technologies; Thermo Fisher Scientific, Inc., Waltham, MA, USA), containing $15 \mathrm{mM}$ 4-(2-hydroxyethyl)-1-piperazineethanesulfonic acid and supplemented with $10 \%$ fetal bovine serum (FBS, Hyclone Laboratories; GE Healthcare Life Sciences, Logan, UT, USA), $100 \mathrm{U} / \mathrm{ml}$ penicillin, $100 \mathrm{mg} / \mathrm{ml}$ streptomycin and $125 \mathrm{ng} / \mathrm{ml}$ amphotericin B. The cells were maintained at $37^{\circ} \mathrm{C}$ in a humidified atmosphere with $5 \% \mathrm{CO}_{2}$.

Cytotoxicity assay. Cells at $80 \%$ confluence were harvested by trypsinization from culture flasks and seeded in 96-well plates at $10^{4}$ cells per $100 \mu \mathrm{l}$ per well. After $24 \mathrm{~h}$ incubation, the cells were treated with apigenin (Sigma-Aldrich; Merck KGaA, Darmstadt, Germany) at various concentrations (1-250 $\mu \mathrm{M})$ for 24, 48 and $72 \mathrm{~h}$. Each well was then replaced with fresh medium containing $0.5 \mathrm{mg} / \mathrm{ml}$ MTT (Sigma-Aldrich; Merck $\mathrm{KGaA}$ ) and incubated for $2 \mathrm{~h}$. Finally, the medium was removed and $100 \mu \mathrm{l}$ dimethyl sulfoxide was added to each well. The absorbance was measured at $550 \mathrm{~nm}$ with a microplate reader, subtracted with the absorbance at $650 \mathrm{~nm}$. Data were expressed as \% cell growth compared with the untreated cells as the control.

Detection of apoptosis. Apoptosis was detected by two different methods, flow cytometric analysis of phosphatidylserine externalization and a DNA fragmentation assay. For the flow cytometric analysis, the HuCCA-1 cells were seeded in 6 -well plate at $4 \times 10^{5}$ cells per $2 \mathrm{ml}$ per well. After $24 \mathrm{~h}$ incubation, the cells were treated with apigenin at concentrations of $20 \%$ inhibition of cell growth $\left(\mathrm{IC}_{20}\right), 25 \mu \mathrm{M}, \mathrm{IC}_{50}, 75 \mu \mathrm{M}$ and $\mathrm{IC}_{90}, 200 \mu \mathrm{M}$, respectively. After $48 \mathrm{~h}$ of compound treatment, floating cells in culture media were separated whilst adherent cells were harvested by trypsinization, then the two cell populations were pooled together and centrifuged at $778 \mathrm{x} \mathrm{g}$ for $10 \mathrm{~min}$ at $4^{\circ} \mathrm{C}$. The supernatant was removed and the cell pellets were resuspended and adjusted to $1 \times 10^{6}$ cells $/ \mathrm{ml}$ in culture media containing $1 \% \mathrm{FBS}$. Equal volumes of the cell suspension and reagent of Muse ${ }^{\mathrm{TM}}$ Annexin-V \& Dead Cell kit (Merck KGaA) were mixed together in a tube and incubated at room temperature for $20 \mathrm{~min}$, and analysis was performed using Muse ${ }^{\mathrm{TM}}$ Cell Analyzer (Merck KGaA) (23). For the DNA fragmentation assay, after $48 \mathrm{~h}$ of compound treatment, floating cells in culture media were harvested by centrifugation at $778 \mathrm{x}$ g for $10 \mathrm{~min}$ at $4^{\circ} \mathrm{C}$, whilst adherent cells were harvested by scraping in cold $1 \mathrm{X}$ PBS followed by the centrifugation at $778 \mathrm{x}$ g for $10 \mathrm{~min}$ to collect the cells. Subsequent to this step, the cell pellets were subjected to DNA extraction using the QIAamp DNA kit (Qiagen $\mathrm{GmbH}$, Hilden, Germany), the isolated DNA fragments were resolved in $2 \%$ agarose gel using electrophoresis and then visualized by staining with ethidium bromide.

Sample preparation and protein extraction. Tissue culture flasks measuring $75 \mathrm{~cm}^{2}$ were used for seeding HuCCA-1 cells and the cells were cultured at $37^{\circ} \mathrm{C}, 5 \% \mathrm{CO}_{2}$ for $24 \mathrm{~h}$. Apigenin was then added to the cells at final concentration of $200 \mu \mathrm{M}$, $90 \%$ inhibition, $\mathrm{IC}_{90}$, for $48 \mathrm{~h}$. Since apigenin treatment causes cell detachment, the floating cells were collected from the medium by centrifugation at $778 \mathrm{x}$ g for $10 \mathrm{~min}$ at $4^{\circ} \mathrm{C}$ and washed with $0.25 \mathrm{M}$ sucrose-containing protease inhibitor cocktail (Sigma-Aldrich; Merck KGaA). The adherent cells were harvested by trypsinization and washed twice with $0.25 \mathrm{M}$ sucrose, scraped in the same sucrose solution and centrifuged at $778 \mathrm{x}$ g for $10 \mathrm{~min}$ at $4^{\circ} \mathrm{C}$. The two samples were resuspended in $100 \mu \mathrm{l}$ lysis buffer containing $7 \mathrm{M}$ urea, $2 \mathrm{M}$ thiourea, 4\% CHAPS, 2\% dithiothreitol (DTT), 2\% ampholine pH 3-10 and a protease inhibitor cocktail, sonicated on ice and centrifuged at $13,800 \mathrm{x} \mathrm{g}$ for $10 \mathrm{~min}$ at $4^{\circ} \mathrm{C}$. The supernatants were saved and the concentration of proteins was determined using the Bio-Rad Protein Assay (Bio-Rad Laboratories, Inc., Hercules, CA, USA).

Two-dimensional gel electrophoresis. The samples were prepared by leaving them overnight in gel rehydration of nonlinear pH 3-10, 70-mm Immobiline DryStrip gels (IPG; GE Healthcare, Chalfont, UK). An Ettan IPGphor system (GE Healthcare) was used for running the first dimension isoelectric focusing at $6,500 \mathrm{Vh}$. The IPG strips were equilibrated in two steps of equilibration buffer as previously described (10). For running the second-dimension electrophoresis, $12.5 \%$ SDS-PAGE was prepared, the IPG strips were placed in the Hoefer minigels and electrophoresis was performed at $20 \mathrm{~mA}$ for 2 h. Coomassie Brilliant Blue R-250 (0.1\%) in 40\% methanol and $10 \%$ acetic acid was used as the staining solution.

Gel scanning and image analysis. The gels were scanned using ImageScanner II (GE Healthcare) and analyzed using ImageMaster 2D platinum software (version 7.0; GE Healthcare) for differential analysis.

In-gel digestion. The triplicate washing step was performed by adding $50 \mu \mathrm{l} 0.1 \mathrm{M} \mathrm{NH}_{4} \mathrm{HCO}_{3}$ in $50 \%$ acetonitrile (ACN) in excised gel spots and incubating for $20 \mathrm{~min}$ at $30^{\circ} \mathrm{C}$. The gel pieces were dried completely in SpeedVac (Labconco, Kansas City, MO, USA). The gel pieces were reduced and alkylated in $1 \mathrm{X}$ buffer solution, $0.1 \mathrm{M} \mathrm{NH}_{4} \mathrm{HCO}_{3}, 10 \mathrm{mM}$ DTT and $1 \mathrm{mM}$ 
EDTA, and incubated at $60^{\circ} \mathrm{C}$ for $45 \mathrm{~min}$. The buffer solution was replaced with freshly prepared $100 \mathrm{mM}$ iodoacetamide in $0.1 \mathrm{M} \mathrm{NH}_{4} \mathrm{HCO}_{3}$ solution. The reaction mixture was incubated in the dark at room temperature for $30 \mathrm{~min}$. The gel pieces were washed three times using 50\% ACN in water and were dried completely. The trypsin (Promega Corporation, Madison, WI, USA) was aliquoted ( $1 \mu \mathrm{g}$ trypsin/10 $\mu \mathrm{l} 1 \%$ acetic acid) and stored at $-20^{\circ} \mathrm{C}$. The digestion buffer, $0.05 \mathrm{M}$ Tris- $\mathrm{HCl}, 10 \%$ ACN, $1 \mathrm{mM} \mathrm{CaCl}_{2}$, pH 8.5, was prepared. The tryptic digestion was performed by adding $50 \mu \mathrm{l}$ digestion buffer and $1 \mu \mathrm{l}$ prepared trypsin into the gel pieces. The reaction mixture was incubated at $37^{\circ} \mathrm{C}$ overnight. The digestion buffer was removed and saved. The gel pieces were then added to $60 \mu 12 \%$ freshly prepared trifluoroacetic acid and incubated at $60^{\circ} \mathrm{C}$ for $30 \mathrm{~min}$ for peptide extraction. The saved digestion buffer and the final extract were then pooled and dried by SpeedVac.

Protein identification by liquid chromatography (LC) tandem mass spectrometry (MS/MS). The Q-TOF mass spectrometer (Micromass UK, Ltd., Manchester, UK) equipped with a $\mathrm{Z}$-spray ion source operating in the nanoelectrospray mode was used. The analysis by LC was carried out using a capillary LC system (Waters Corporation, Milford, MA, USA). The instrument in MS/MS mode was calibrated by Glu-fibrinopeptide. The 75 mm id x150 mm C18 PepMap column (LC Packings, Amsterdam, The Netherlands) was attached to the LC system. Eluents A and B were prepared as follows: Eluent A, $0.1 \%$ formic acid in $97 \%$ water and $3 \% \mathrm{ACN}$ and eluent $\mathrm{B}, 0.1 \%$ formic acid in $97 \% \mathrm{ACN}$ and $3 \%$ water. The gradient for peptide separation was $0 \mathrm{~min} 7 \% \mathrm{~B}, 35 \mathrm{~min} 50 \% \mathrm{~B}, 45 \mathrm{~min} 80 \%$ B, $49 \min 80 \%$ B, 50 min $7 \%$ B and $60 \min 7 \%$ B. ProteinLynx Global SERVER ${ }^{\mathrm{TM}}$ (version 2.2; Waters Corporation) screening Swiss-Prot and NCBI (https://www.ncbi.nlm .nih.gov/) was employed for database search. The MASCOT (http://www.matrixscience.com) search tool available on the Matrix Science site screening and NCBInr was also used to confirm certain proteins.

Western blot analysis. The untreated and apigenin treated HuCCA-1 cells were scraped separately and sonicated in an in-house $1 \mathrm{X}$ radioimmunoprecipitation assay (RIPA) buffer (150 mM NaCl, 1\% Triton X-100, 0.5\% sodium deoxycholate, $0.1 \%$ SDS, $50 \mathrm{mM}$ Tris pH 8.0 and $1 \mathrm{mM}$ EDTA) to extract the proteins. Protein lysates $(20 \mu \mathrm{g})$ were subsequently loaded in each lane. Proteins separation was performed by $12.5 \%$ SDS-PAGE and transferred onto FluoroTrans ${ }^{\circledR}$ polyvinylidene difluoride membranes (Pall Corporation, Port Washington, NY, USA). Subsequent to blocking with 5\% nonfat dried milk in TBS-Tween 20 (TBST), $10 \mathrm{mM}$ Tris, pH 7.6, $150 \mathrm{mM} \mathrm{NaCl}$, $0.1 \%$ Tween 20 , at room temperature for $1 \mathrm{~h}$, the membranes were washed with TBST and incubated with the following primary antibodies: Mouse monoclonal cytokeratin 7 (CK7; cat. no. MAB3554; dilution, 1:2,000; Merck KGaA); mouse monoclonal cytokeratin 8 (CK8; cat. no. MAB3414; dilution, 1:2,000; Merck KGaA); mouse monoclonal cytokeratin 18 (CK18; cat. no. MAB3236; dilution, 1:2,000; Merck KGaA); mouse monoclonal cytokeratin 19 (CK19; cat. no. MAB3238; dilution, 1:2,000; Merck KGaA); mouse monoclonal S100-A6 (cat. no. ab55680; dilution, 1:250; Abcam, Cambridge, UK); rabbit polyclonal S100-A11 (cat. no. 10237-1-AP; dilution,
1:250; Proteintech, Chicago, IL, USA); rabbit monoclonal S100-P (cat. no. ab133554; dilution, 1:1,000; Abcam); mouse monoclonal heterogeneous nuclear ribonucleoprotein A2/B1 (hnRNP A2/B1; cat. no. ab6102; dilution, 1:2,000; Abcam); rabbit polyclonal heterogeneous nuclear ribonucleoprotein H (hnRNP H; cat. no. ab10374; dilution, 1:5,000; Abcam); mouse monoclonal annexin A1 (cat. no. MAB3773; dilution, 1:2,000; Merck KGaA); mouse monoclonal annexin A2 (cat. no. ab54771; dilution, 1:20,000; Abcam); rabbit polyclonal annexin A3 (cat. no. ab33068; dilution, 1:2,000; Abcam); mouse monoclonal peroxiredoxin-1 (cat. no. ab58252; dilution, 1:2,000; Abcam); mouse monoclonal prostaglandin E synthase 3 (PTGES3; cat. no. WH0010728M1; dilution, 1:500; Sigma-Aldrich; Merck KGaA); or rabbit monoclonal GAPDH (cat. no. ab75834; dilution, 1:10,000; Abcam) at $4^{\circ} \mathrm{C}$ overnight. The membranes were then washed with TBST and incubated with horseradish peroxidase-conjugated anti-mouse or anti-rabbit antibodies (Dako; Agilent technologies, Inc., Santa Clara, CA, USA) at room temperature for $1 \mathrm{~h}$. Following washing with TBST, membranes were visualized by using an enhanced chemiluminescence Western blotting detection kit (Advansta, Menlo Park, CA, USA) and an ImageQuant LAS 4000 mini (GE Healthcare). A total of three experiments were performed for each antibody.

Statistical analysis. The mean values and standard deviations of differential expression between treated and untreated cells were calculated. The significance of differences was analyzed by two-tailed unpaired Student's $t$ tests, and $\mathrm{P}<0.05$ was considered to indicate a statistically significant difference.

\section{Results}

Apigenin inhibited the growth of HuCCA-1 cells. The MTT assay was performed to investigate the growth inhibition and assess the cytotoxic effect of apigenin. HuCCA-1 cells were treated with various concentrations of apigenin ranging from 1-250 $\mu \mathrm{M}$ at different times. The results in Fig. 1A illustrate the dose- and time-dependent inhibition of cell growth by apigenin. Since cell morphology changes were being observed at $48 \mathrm{~h}$ subsequent to treatment as demonstrated in Fig. 1B, the results at this time point were chosen to estimate the value of concentrations that will cause $\mathrm{IC}_{20}, \mathrm{IC}_{50}$ and $\mathrm{IC}_{90}$. The values of $\mathrm{IC}_{20}, \mathrm{IC}_{50}$ and $\mathrm{IC}_{90}$ of apigenin after $48 \mathrm{~h}$ treatment were 25, 75 and $200 \mu \mathrm{M}$, respectively. After $48 \mathrm{~h}$ incubation, the morphology changes were clearly observed in treated cells at concentrations up to $200 \mu \mathrm{M}$ compared with the control. The treated cells appeared to lack regular shape with boundaries resembling loosely adhered cells.

Apigenin induced apoptosis in HuCCA-1 cells. To examine whether apigenin induced apoptotic cell death in HuCCA-1 cells, two different methods were used to detect apoptosis, flow cytometric analysis of phosphatidylserine (PS) externalization and DNA fragmentation assays. When cells undergo apoptosis, an early event is PS externalization on the cell surface, which are detected by Annexin-V staining. Subsequent to the progression to late stage of apoptosis, the membrane integrity of the cells is lost, allowing penetration of membrane-impermeant dyes such as 7-aminoactinomycin D (7-AAD) and propidium 
Table I. Differentially expressed proteins of HuCCA-1 following apigenin treatment.

\begin{tabular}{|c|c|c|c|c|c|}
\hline $\begin{array}{l}\text { Spot } \\
\text { no. }\end{array}$ & $\begin{array}{l}\text { Accession } \\
\text { no. }\end{array}$ & Protein names & $\begin{array}{c}\text { Theoretical } \\
\mathrm{pI} / \mathrm{MW}\end{array}$ & Function & $\begin{array}{c}\text { Fold } \\
\text { Change }^{\mathrm{a}}\end{array}$ \\
\hline 1 & Q9Y4L1 & Hypoxia up-regulated protein 1 & $5.21 / 111.3$ & Chaperone/stress response & $-2.04 \pm 0.17^{b}$ \\
\hline 2 & Q16822 & $\begin{array}{l}\text { Phosphoenolpyruvate carboxykinase } \\
{[\mathrm{GTP}] \text {, mitochondrial }}\end{array}$ & $7.40 / 70.6$ & Metabolism & ND \\
\hline 3 & P31939 & $\begin{array}{l}\text { Bifunctional purine biosynthesis } \\
\text { protein PURH }\end{array}$ & $6.26 / 64.6$ & Metabolism & $-16.21 \pm 0.35^{\mathrm{d}}$ \\
\hline 4 & P10809 & $\begin{array}{l}60 \mathrm{kDa} \text { heat shock protein, } \\
\text { mitochondrial }\end{array}$ & $5.55 / 61.0$ & Chaperone/stress response & $-2.12 \pm 0.48^{b}$ \\
\hline 5 & P31948 & Stress-induced-phosphoprotein 1 & $6.76 / 62.6$ & Chaperone/stress response & $+1.58 \pm 0.03^{\mathrm{c}}$ \\
\hline 6 & P07437 & Tubulin beta chain & $4.59 / 49.6$ & Cytoskeleton/mobility & $+2.19 \pm 0.39^{c}$ \\
\hline 7 & P08729 & Keratin, type II cytoskeletal 7 & $5.46 / 51.2$ & Cytoskeleton/mobility & $-2.51 \pm 0.13^{c}$ \\
\hline 8 & P08729 & Keratin, type II cytoskeletal 7 & $5.46 / 51.2$ & Cytoskeleton/mobility & $-5.33 \pm 0.41^{\mathrm{c}}$ \\
\hline 9 & P31943 & $\begin{array}{l}\text { Heterogeneous nuclear } \\
\text { ribonucleoprotein } \mathrm{H}\end{array}$ & $6.21 / 49.2$ & $\begin{array}{l}\text { Protein synthesis } \\
\text { and degradation }\end{array}$ & $-26.66 \pm 0.51^{c}$ \\
\hline 10 & Q16658 & Fascin & $7.28 / 54.4$ & Cytoskeleton/mobility & $-1.22 \pm 0.02^{\mathrm{c}}$ \\
\hline 11 & P43490 & $\begin{array}{l}\text { Nicotinamide } \\
\text { phosphoribosyltransferase }\end{array}$ & $7.12 / 55.5$ & Metabolism & $-2.77 \pm 0.14^{\mathrm{b}}$ \\
\hline 12 & P05787 & Keratin, type II cytoskeletal 8 & $5.52 / 53.5$ & Cytoskeleton/mobility & $-6.94 \pm 0.42^{\mathrm{d}}$ \\
\hline 13 & P05787 & Keratin, type II cytoskeletal 8 & $5.52 / 53.5$ & Cytoskeleton/mobility & $-2.82 \pm 0.18^{\mathrm{b}}$ \\
\hline 13 & P05783 & Keratin, type I cytoskeletal 18 & $5.42 / 47.9$ & Cytoskeleton/mobility & $-2.82 \pm 0.18^{b}$ \\
\hline 14 & P05787 & Keratin, type II cytoskeletal 8 & $5.52 / 53.5$ & Cytoskeleton/mobility & $-21.08 \pm 0.90^{c}$ \\
\hline 14 & P05783 & Keratin, type I cytoskeletal 18 & $5.42 / 47.9$ & Cytoskeleton/mobility & $-21.08 \pm 0.90^{c}$ \\
\hline 15 & P05787 & Keratin, type II cytoskeletal 8 & $5.58 / 53.5$ & Cytoskeleton/mobility & $-3.48 \pm 0.17^{c}$ \\
\hline 15 & P05783 & Keratin, type I cytoskeletal 18 & $5.42 / 47.9$ & Cytoskeleton/mobility & $-3.48 \pm 0.17^{\mathrm{c}}$ \\
\hline 16 & P06733 & Alpha-enolase & $7.54 / 47.0$ & Metabolism & $-4.79 \pm 0.68^{c}$ \\
\hline 17 & P08727 & Keratin, type I cytoskeletal 19 & $5.09 / 44.1$ & Cytoskeleton/mobility & ND \\
\hline 18 & P08865 & 40S ribosomal protein SA & $4.59 / 32.8$ & $\begin{array}{l}\text { Protein synthesis and } \\
\text { degradation }\end{array}$ & $-1.81 \pm 0.04^{b}$ \\
\hline 19 & P07910 & $\begin{array}{l}\text { Heterogeneous nuclear } \\
\text { ribonucleoproteins } \mathrm{C} 1 / \mathrm{C} 2\end{array}$ & $4.99 / 33.6$ & $\begin{array}{l}\text { Protein synthesis and } \\
\text { degradation }\end{array}$ & $-2.01 \pm 0.12^{\mathrm{c}}$ \\
\hline 20 & P06748 & Nucleophosmin & $4.71 / 30.9$ & $\begin{array}{l}\text { Protein synthesis } \\
\text { and degradation }\end{array}$ & $-1.63 \pm 0.16^{\mathrm{b}}$ \\
\hline 21 & P07910 & $\begin{array}{l}\text { Heterogeneous nuclear } \\
\text { ribonucleoproteins } \mathrm{C} 1 / \mathrm{C} 2\end{array}$ & $4.99 / 33.6$ & $\begin{array}{l}\text { Protein synthesis } \\
\text { and degradation }\end{array}$ & $-4.64 \pm 0.49^{b}$ \\
\hline 22 & P05388 & $\begin{array}{l}60 \mathrm{~S} \text { acidic ribosomal } \\
\text { protein } \mathrm{P} 0\end{array}$ & $5.60 / 34.3$ & $\begin{array}{l}\text { Protein synthesis } \\
\text { and degradation }\end{array}$ & $-1.42 \pm 0.03^{b}$ \\
\hline 23 & Q15365 & Poly(rC)-binding protein 1 & $7.11 / 37.5$ & $\begin{array}{l}\text { Protein synthesis } \\
\text { and degradation }\end{array}$ & $-5.59 \pm 0.14^{\mathrm{b}}$ \\
\hline 24 & O00154 & $\begin{array}{l}\text { Cytosolic acyl coenzyme A } \\
\text { thioester hydrolase }\end{array}$ & $7.27 / 37.4$ & Metabolism & $-19.00 \pm 0.27^{\mathrm{d}}$ \\
\hline 25 & P04083 & Annexin A1 & $7.00 / 38.6$ & Signal transduction & $-2.05 \pm 0.14^{\mathrm{c}}$ \\
\hline 26 & P07355 & Annexin A2 & $8.04 / 38.4$ & Signal transduction & $+3.89 \pm 0.48^{\mathrm{b}}$ \\
\hline 27 & P12429 & Annexin A3 & $5.82 / 36.4$ & Signal transduction & $+4.63 \pm 0.12^{b}$ \\
\hline 28 & Q06323 & $\begin{array}{l}\text { Proteasome activator } \\
\text { complex subunit } 1\end{array}$ & $5.98 / 28.7$ & Cell cycle & $-5.84 \pm 0.10^{b}$ \\
\hline 29 & P04406 & $\begin{array}{l}\text { Glyceraldehyde-3-phosphate } \\
\text { dehydrogenase }\end{array}$ & $8.79 / 35.9$ & Metabolism & ND \\
\hline 30 & P04406 & $\begin{array}{l}\text { Glyceraldehyde-3-phosphate } \\
\text { dehydrogenase }\end{array}$ & $8.79 / 35.9$ & Metabolism & $-1.12 \pm 0.02^{\mathrm{b}}$ \\
\hline 31 & P35232 & Prohibitin & $5.57 / 29.8$ & $\begin{array}{l}\text { DNA replication/ } \\
\text { gene regulation }\end{array}$ & $-1.22 \pm 0.06^{\mathrm{b}}$ \\
\hline 32 & P02545 & Lamin $\mathrm{A} / \mathrm{C}$ & $6.13 / 53.2$ & Cytoskeleton/mobility & $\mathrm{D}$ \\
\hline
\end{tabular}


Table I. Continued.

\begin{tabular}{|c|c|c|c|c|c|}
\hline $\begin{array}{l}\text { Spot } \\
\text { no. }\end{array}$ & $\begin{array}{l}\text { Accession } \\
\text { no. }\end{array}$ & Protein names & $\begin{array}{c}\text { Theoretical } \\
\mathrm{pI} / \mathrm{MW}\end{array}$ & Function & $\begin{array}{c}\text { Fold } \\
\text { Change }^{\mathrm{a}}\end{array}$ \\
\hline 33 & P48556 & $\begin{array}{l}\text { 26S proteasome non- } \\
\text { ATPase regulatory subunit } 8\end{array}$ & $7.16 / 30.0$ & $\begin{array}{l}\text { Protein synthesis } \\
\text { and degradation }\end{array}$ & $-3.17 \pm 0.05^{\mathrm{b}}$ \\
\hline 34 & Q06830 & Peroxiredoxin-1 & $8.52 / 22.1$ & Protection and detoxification & $-2.41 \pm 0.09^{b}$ \\
\hline 35 & P21796 & $\begin{array}{l}\text { Voltage-dependent anion- } \\
\text { selective channel protein } 1\end{array}$ & $8.85 / 30.6$ & Ion channels & $-1.35 \pm 0.09^{\mathrm{b}}$ \\
\hline 36 & P43487 & $\begin{array}{l}\text { Ran-specific GTPase- } \\
\text { activating protein }\end{array}$ & $5.27 / 23.3$ & $\begin{array}{l}\text { Transport/binding } \\
\text { proteins }\end{array}$ & ND \\
\hline 37 & P28066 & $\begin{array}{l}\text { Proteasome subunit } \\
\text { alpha type- } 5\end{array}$ & $4.54 / 26.4$ & $\begin{array}{l}\text { Protein synthesis } \\
\text { and degradation }\end{array}$ & $+1.82 \pm 0.03^{\mathrm{b}}$ \\
\hline 38 & Q9BV44 & $\begin{array}{l}\text { THUMP domain- } \\
\text { containing protein } 3\end{array}$ & $5.97 / 57.0$ & $\begin{array}{l}\text { Protein synthesis } \\
\text { and degradation }\end{array}$ & $-2.45 \pm 0.03^{b}$ \\
\hline 39 & P05783 & Keratin, type I cytoskeletal 18 & $5.42 / 47.9$ & Cytoskeleton/mobility & $+9.17 \pm 0.15^{\mathrm{b}}$ \\
\hline 40 & P25789 & Proteasome subunit alpha type-4 & $8.04 / 29.5$ & $\begin{array}{l}\text { Protein synthesis } \\
\text { and degradation }\end{array}$ & $-2.13 \pm 0.07^{c}$ \\
\hline 41 & P62333 & $26 \mathrm{~S}$ protease regulatory subunit $10 \mathrm{~B}$ & $7.09 / 44.2$ & $\begin{array}{l}\text { Protein synthesis } \\
\text { and degradation }\end{array}$ & ND \\
\hline 42 & Q15056 & $\begin{array}{l}\text { Eukaryotic translation } \\
\text { initiation factor } 4 \mathrm{H}\end{array}$ & $7.33 / 27.4$ & $\begin{array}{l}\text { Protein synthesis } \\
\text { and degradation }\end{array}$ & $-3.62 \pm 0.10^{b}$ \\
\hline 43 & Q06830 & Peroxiredoxin-1 & $8.52 / 22.1$ & $\begin{array}{l}\text { Protection and } \\
\text { detoxification }\end{array}$ & $-6.52 \pm 0.41^{c}$ \\
\hline 44 & P13693 & $\begin{array}{l}\text { Translationally-controlled } \\
\text { tumor protein }\end{array}$ & $4.84 / 19.6$ & Transport/binding proteins & $-2.11 \pm 0.07^{b}$ \\
\hline 45 & O75947 & $\begin{array}{l}\text { ATP synthase subunit d, } \\
\text { mitochondrial }\end{array}$ & $5.26 / 18.3$ & Metabolism & $-1.31 \pm 0.02^{\mathrm{b}}$ \\
\hline 46 & P32119 & Peroxiredoxin-2 & $5.86 / 21.9$ & $\begin{array}{l}\text { Protection and } \\
\text { detoxification }\end{array}$ & $-3.20 \pm 0.11^{b}$ \\
\hline 47 & Q15185 & Prostaglandin E synthase 3 & $4.30 / 18.7$ & Chaperone/stress response & ND \\
\hline 48 & O00746 & $\begin{array}{l}\text { Nucleoside diphosphate } \\
\text { kinase, mitochondrial }\end{array}$ & $9.21 / 17.3$ & Metabolism & $+12.27 \pm 0.35^{\mathrm{b}}$ \\
\hline 49 & P05783 & Keratin, type I cytoskeletal 18 & $5.42 / 47.9$ & Cytoskeleton/mobility & $\mathrm{D}$ \\
\hline 50 & P16949 & Stathmin & $5.96 / 17.2$ & Cytoskeleton/mobility & ND \\
\hline 51 & Q93020 & $\begin{array}{l}\text { GTP-binding regulatory } \\
\text { protein } \mathrm{Gi} \text { alpha- } 2 \text { chain }\end{array}$ & $5.30 / 22.1$ & Signal transduction & $-3.64 \pm 0.18^{b}$ \\
\hline 52 & P23528 & Cofilin-1 & $8.22 / 18.5$ & Cytoskeleton/mobility & ND \\
\hline 53 & P08727 & Keratin, type I cytoskeletal 19 & $5.09 / 44.1$ & Cytoskeleton/mobility & $\mathrm{D}$ \\
\hline 54 & P23528 & Cofilin-1 & $8.22 / 18.5$ & Cytoskeleton/mobility & $+2.46 \pm 0.13^{\mathrm{b}}$ \\
\hline 55 & P62937 & $\begin{array}{l}\text { Peptidyl-prolyl cis-trans } \\
\text { isomerase A }\end{array}$ & $8.18 / 17.9$ & Signal transduction & $-4.24 \pm 0.66^{c}$ \\
\hline 56 & P62937 & $\begin{array}{l}\text { Peptidyl-prolyl cis-trans } \\
\text { isomerase A }\end{array}$ & $8.18 / 17.9$ & Signal transduction & $-10.17 \pm 0.46^{\mathrm{d}}$ \\
\hline 57 & P22392 & $\begin{array}{l}\text { Nucleoside diphosphate } \\
\text { kinase B }\end{array}$ & $8.52 / 17.3$ & Metabolism & $-1.83 \pm 0.13^{\mathrm{b}}$ \\
\hline 58 & P25398 & $40 \mathrm{~S}$ ribosomal protein $\mathrm{S} 12$ & $6.30 / 14.5$ & $\begin{array}{l}\text { Protein synthesis } \\
\text { and degradation }\end{array}$ & $-2.35 \pm 0.10^{\mathrm{b}}$ \\
\hline 59 & Q9UII2 & ATPase inhibitor, mitochondrial & $9.34 / 12.2$ & Metabolism & ND \\
\hline 60 & P06703 & Protein S100-A6 & $5.32 / 10.2$ & Cytoskeleton/mobility & $\mathrm{D}$ \\
\hline 61 & P31949 & Protein S100-A11 & $7.27 / 11.7$ & Cytoskeleton/mobility & $+4.13 \pm 0.12^{b}$ \\
\hline 62 & P04075 & $\begin{array}{l}\text { Fructose-bisphosphate } \\
\text { aldolase A }\end{array}$ & $8.06 / 39.4$ & Metabolism & ND \\
\hline 63 & Q04828 & $\begin{array}{l}\text { Aldo-keto reductase family } \\
1 \text { member } \mathrm{C} 1\end{array}$ & $8.25 / 36.8$ & Protection and detoxification & ND \\
\hline
\end{tabular}


Table I. Continued.

\begin{tabular}{|c|c|c|c|c|c|}
\hline $\begin{array}{l}\text { Spot } \\
\text { no. }\end{array}$ & $\begin{array}{l}\text { Accession } \\
\text { no. }\end{array}$ & Protein names & $\begin{array}{c}\text { Theoretical } \\
\mathrm{pI} / \mathrm{MW}\end{array}$ & Function & $\begin{array}{c}\text { Fold } \\
\text { Change }^{\mathrm{a}}\end{array}$ \\
\hline 64 & P22626 & $\begin{array}{l}\text { Heterogeneous nuclear } \\
\text { ribonucleoproteins A2/B1 }\end{array}$ & $9.12 / 37.4$ & $\begin{array}{l}\text { Protein synthesis and } \\
\text { degradation }\end{array}$ & $-4.56 \pm 0.75^{b}$ \\
\hline 65 & P04406 & $\begin{array}{l}\text { Glyceraldehyde-3-phosphate } \\
\text { dehydrogenase }\end{array}$ & $8.79 / 35.9$ & Metabolism & $-1.46 \pm 0.40^{\mathrm{b}}$ \\
\hline 66 & P22626 & $\begin{array}{l}\text { Heterogeneous nuclear } \\
\text { ribonucleoproteins A2/B1 }\end{array}$ & $9.12 / 37.4$ & $\begin{array}{l}\text { Protein synthesis and } \\
\text { degradation }\end{array}$ & ND \\
\hline 67 & P04406 & $\begin{array}{l}\text { Glyceraldehyde-3-phosphate } \\
\text { dehydrogenase }\end{array}$ & $8.79 / 35.9$ & Metabolism & $-7.70 \pm 0.92^{c}$ \\
\hline
\end{tabular}

-, downregulated expression following treatment; +, upregulated expression following treatment; D, appearance of proteins upon treatment; $\mathrm{ND}$, disappearance of proteins upon treatment; $\mathrm{pI}$, isoelectric point; $\mathrm{MW}$, molecular weight. ${ }^{\mathrm{F}}$ Fold change of protein expression was calculated from three independent experiments. ${ }^{\mathrm{b}} \mathrm{P}<0.05,{ }^{\mathrm{c}} \mathrm{P}<0.01,{ }^{\mathrm{d}} \mathrm{P}<0.001$.
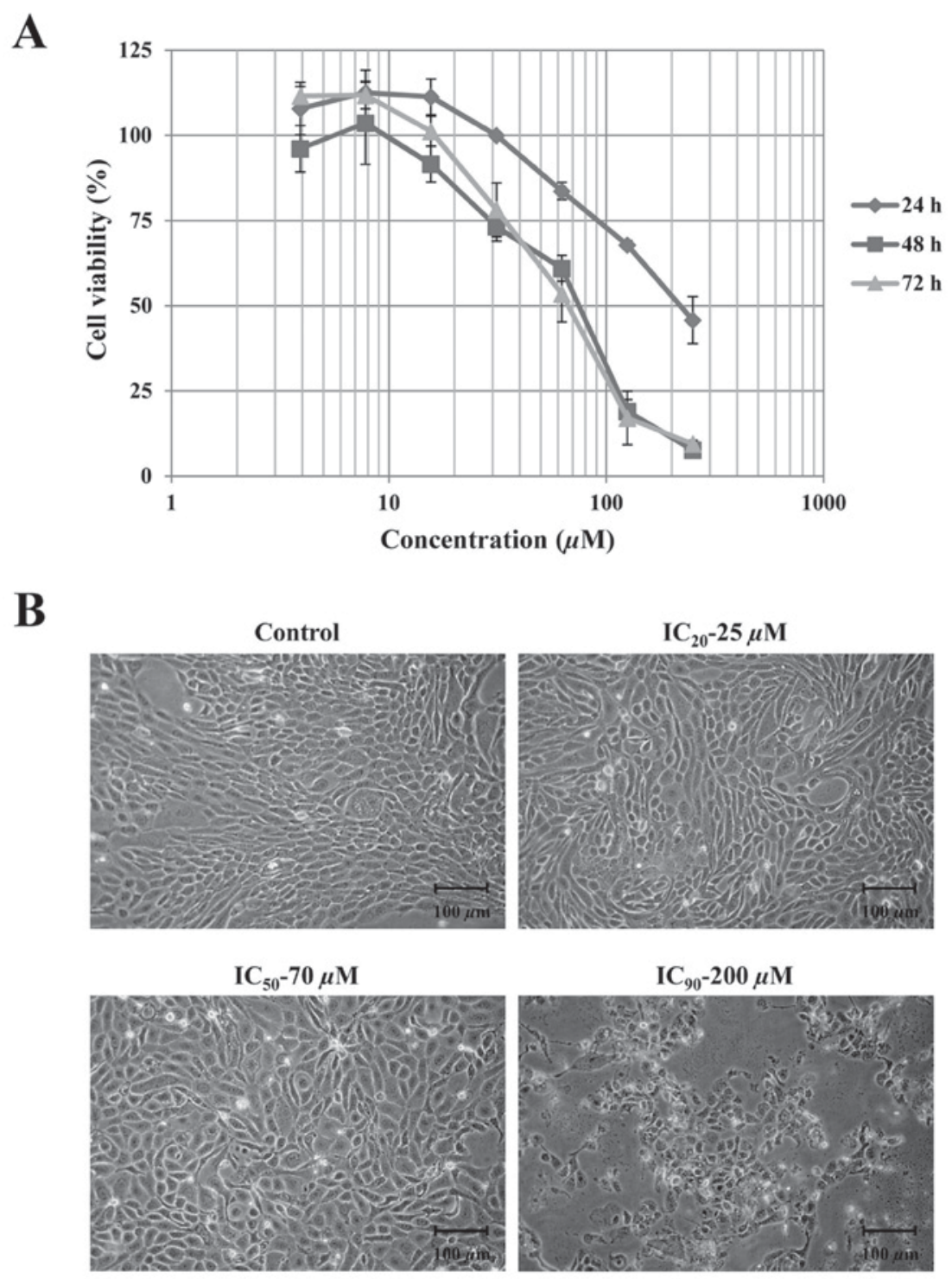

Figure 1. Effect of apigenin on cell growth. (A) Treatment of HuCCA-1 cells by various concentration of apigenin (1-250 $\mu \mathrm{M})$ for 24,48 and $72 \mathrm{~h}$. The number of surviving cell was calculated by MTT assay. The presented data are as mean \pm standard deviation of three different experiments. (B) The cells were treated with apigenin at concentrations of 20,50 and $90 \%$ growth inhibition, $\mathrm{IC}_{20}, \mathrm{IC}_{50}$ and $\mathrm{IC}_{90}$, respectively. The cells were observed by inverted phase-contrast microscopy (magnification, x100). 
A

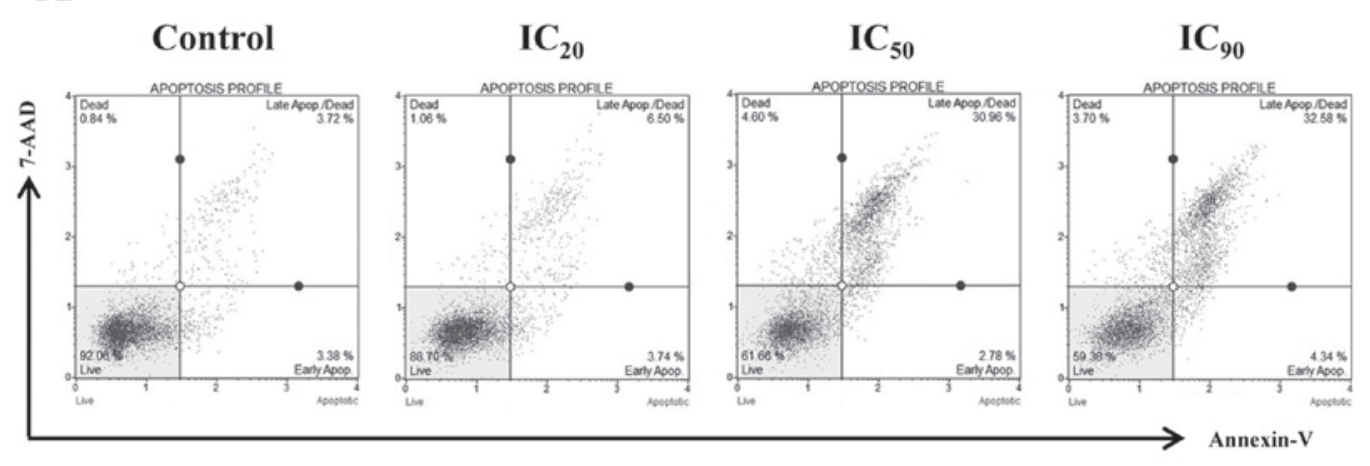

B

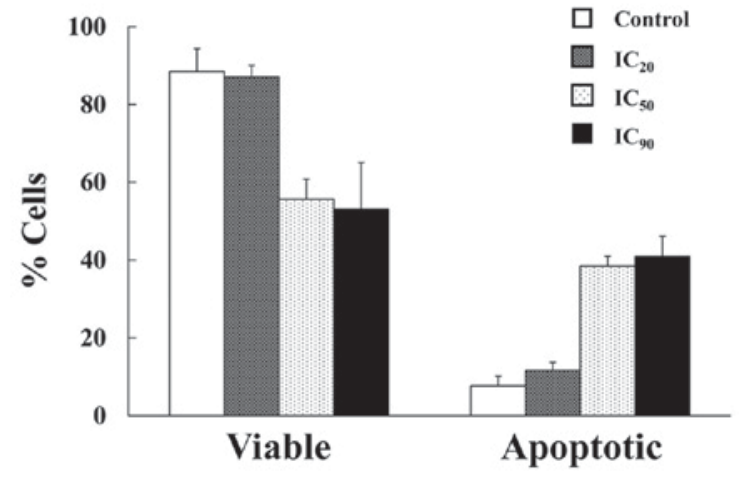

C

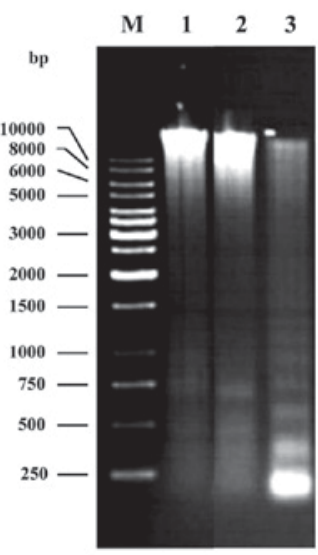

Figure 2. Apigenin induces apoptosis in HuCCA-1 cells. (A and B) Flow cytometric analysis of apoptotic cells was performed by using Muse ${ }^{\mathrm{TM}}$ Cell Analyzer with Muse $^{\mathrm{TM}}$ Annexin-V \& Dead Cell kit. The treatment of HuCCA-1 cells was performed with $0.2 \%$ dimethyl sulfoxide (control) or different concentrations of apigenin $(25-200 \mu \mathrm{M})$ for $48 \mathrm{~h}$. Dot plots of flow cytometric results were from three independent experiments. Data are presented as mean \pm standard deviation of three different experiments. (C) Detection of apigenin induced DNA fragmentation in HuCCA-1 cells. HuCCA-1 cells were treated with $200 \mu \mathrm{M}$ apigenin, $\mathrm{IC}_{90}$, for $48 \mathrm{~h}$. Genomic DNA samples were isolated from HuCCA-1 cells with or without apigenin, separation was performed on $2 \%$ agarose gels, and visualized using ethidium bromide staining. Lane M, DNA marker; lane 1, DNA from untreated cells; lane 2, DNA from the attached cells subsequent to treatment; lane 3, DNA from the floating cells subsequent to treatment; 7-ADD, 7-amino actinomycin D.

A

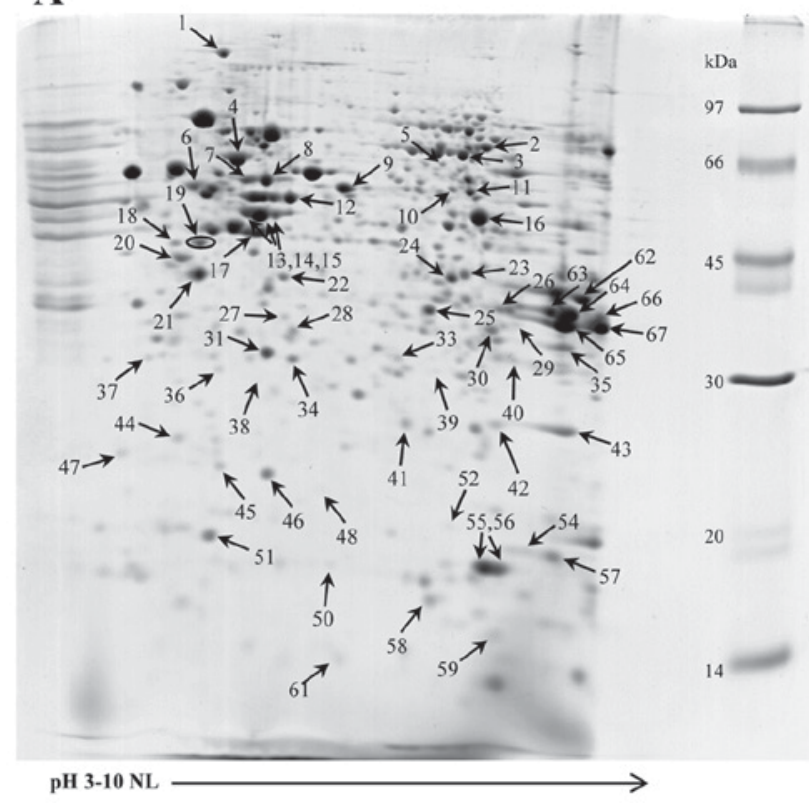

B

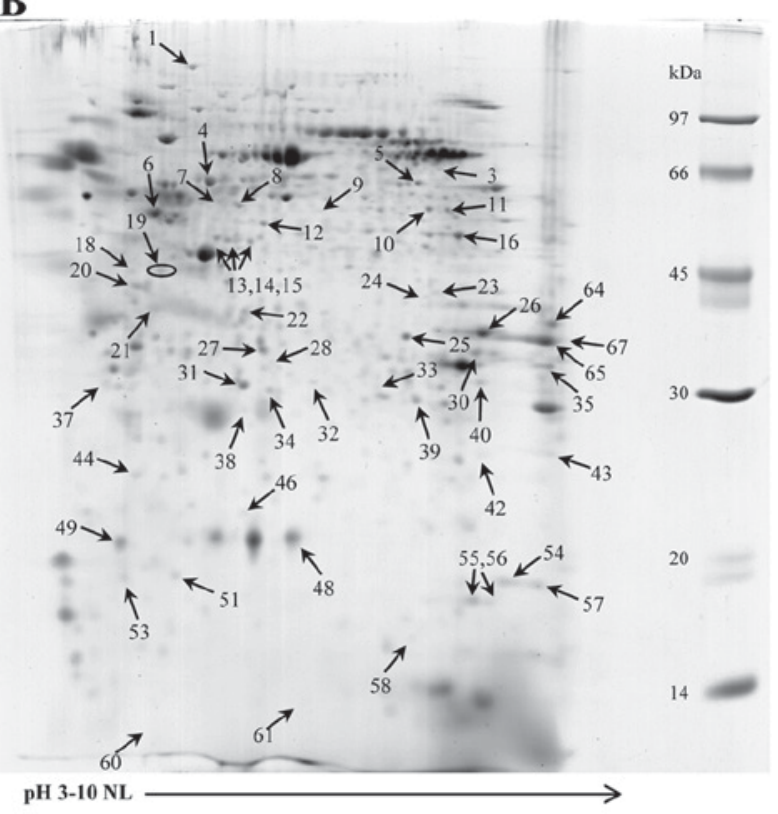

Figure 3. Comparison of 2-DE patterns between untreated and treated HuCCA-1 cells with apigenin. (A and B) Illustrate the 2-DE patterns of untreated and treated cells with $200 \mu \mathrm{M}$ apigenin. NL pH 3-10 Immobiline DryStrip gels were used. Gels were stained with Coomassie Brilliant Blue R-250. Proteins with different expressions are marked by arrows with numbers. Data presented are the representative of three totally different experiments. 2-DE, two-dimensional gel electrophoresis; NL, non-linear. 

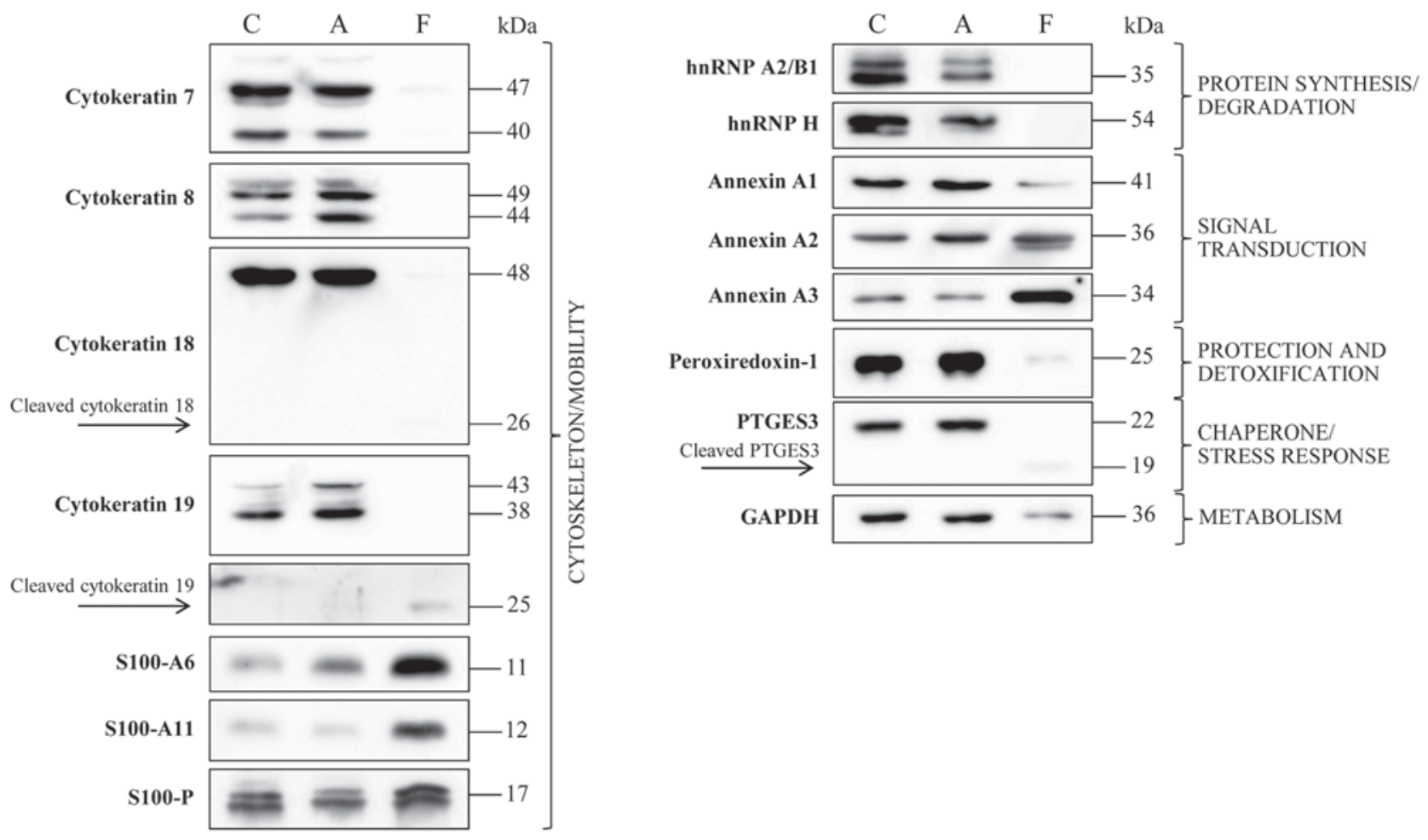

Figure 4. Western blot analysis of proteins in untreated cells compared with adherent and floating cells subsequent to treatment with apigenin. C, control untreated cells; A, adherent cells; F, floating cells subsequent to treatment with apigenin, respectively. hnRNP A2/B1, heterogeneous nuclear ribonucleoprotein A2/B1; PTGES3, prostaglandin E synthase 3; hnRNP H, heterogeneous nuclear ribonucleoprotein $\mathrm{H}$.

iodide. Mode of cell death in apigenin-treated HuCCA-1 cells was analyzed. The cells were treated with increasing concentration from $\mathrm{IC}_{20}, 25 \mu \mathrm{M}, \mathrm{IC}_{50}, 75 \mu \mathrm{M}$ and $\mathrm{IC}_{90}, 200 \mu \mathrm{M}$ of apigenin compared with the untreated control for $48 \mathrm{~h}$. Subsequent to the treatment, the cells that were positive for Annexin- $V$ and 7-AAD staining with stages of early and late apoptosis were detected (Fig. 2A). The percentage of total apoptotic cell populations, early and late apoptosis, increased corresponding to the higher concentration of apigenin. The highest proportion of apoptotic cells was $\sim 41 \%$, when cells were treated with apigenin at a concentration of $\mathrm{IC}_{90}$ (Fig. 2B).

Additionally, another key feature of apoptosis, DNA fragmentation with a ladder pattern, was also investigated. The HuCCA-1 cells were treated with $\mathrm{IC}_{90}, 200 \mu \mathrm{M}$, apigenin for $48 \mathrm{~h}$, and subsequently analyzed for DNA fragmentation. As demonstrated in Fig. 2C, the ladder pattern of DNA fragmentation was observed in floating cells whilst the attached cells exhibited no visible DNA laddering. Taken together, the results of flow cytometric analysis and DNA fragmentation assay consistently indicated that apigenin induced apoptosis in HuCCA-1 cells.

Differential expression of proteins in HuCCA-1 when treated with apigenin.From the DNA fragmentation of apigenin-treated HuCCA-1 cells, apoptosis was clearly demonstrated in the floating cells. Thus, the levels of protein expression in the untreated and apigenin-treated cells floating and adherent cells were compared using proteomic techniques. Only the floating cells demonstrated differential protein expression when compared with the untreated cells by 2-DE. Fig. 3A and $\mathrm{B}$ illustrates the 2-DE patterns of the untreated and floating cells treated with $200 \mu \mathrm{M}$ apigenin, $90 \%$ inhibition, $\mathrm{IC}_{90}$, for $48 \mathrm{~h}$. A total of sixty-seven proteins were revealed to exhibit differential expression and were identified by comparison to the proteins previously examined in the reference map of HuCCA-1 (11) and using LC/MS/MS as summarized in Table I. These proteins were categorized by their functions as follow: Metabolism, cytoskeletal/mobility, protein synthesis and degradation, signal transduction, chaperone/stress response, protection and detoxification, transport/binding proteins, cell cycle, ion channels and DNA replication/gene regulation. The fold changes of proteins were calculated by ImageMaster program and included in Table I.

The expression levels of twelve proteins were not measured in HuCCA-1 cell lysate subsequent to apigenin treatment. These proteins are involved in metabolism, cytoskeletal/mobility, protein synthesis and degradation, chaperone/stress response, protection and detoxification and transport/binding. These proteins are phosphoenolpyruvate carboxykinase (GTP; Table I, spot no. 2), GAPDH (Table I, spot no. 29), ATPase inhibitor (Table I, spot no. 59) and fructose-bisphosphate aldolase A (Table I, spot no. 62), CK19 (Table I, spot no. 17), stathmin (Table I, spot no. 50), cofilin-1 (Table I, spot no. 52), 26S protease regulatory subunit 10B (Table I, spot no. 41), hnRNP A2/B1 (Table I, spot no. 66), PTGES3 (Table I, spot no. 47), aldo-keto reductase family1 member C1 (Table I, spot no. 63) and ran-specific GTPase-activating protein (Table I, spot no. 36). The expression of four proteins was identified subsequent to treatment of the cells with apigenin. The proteins are associated with cytoskeleton/mobility, which are lamin A/C (Table I, spot no. 32), CK18 (Table I, spot no. 49), CK19 (Table I, spot no. 53) and protein S100-A6 (Table I, 
spot no. 60). A total of five downregulated proteins demonstrated $>15$-fold lower expression when comparing the 2-DE patterns of treated and untreated cells. They are cytosolic acyl coenzymeA thioester hydrolase (Table I, spot no. 24), bifunctional purine biosynthesis protein PURH (Table I, spot no. 3), CK8 (Table I, spot no. 14), CK18 (Table I, spot no. 14) and hnRNP H (Table I, spot no. 9). A total of seven downregulated proteins demonstrated lower expression in the range of 5- to 15-fold, which are GADPH (Table I, spot no. 67), cytokeratin 8 (Table I, spot no. 12), cytokeratin 7 (Table I, spot no. 8), poly (rC)-binding protein 1 (Table I, spot no. 23), peptidyl-prolyl cis-trans isomerase A (Table I, spot no. 56), peroxiredoxin-1 (Table I, spot no. 43) and proteasome activator complex subunit 1 (Table I, spot no. 28).

For proteins involved in cytoskeleton/mobility function, significant changes were revealed in expression in CK7, CK8, CK18, CK19, S100-A6 and S100-A11 (Table I, spot no. 61). The CK8 and CK18 proteins were identified in spots 13,14 and 15 whose intensities decreased upon treatment with apigenin. Notably, two novel spots belonging to CK18 at a molecular weight (MW) 29.9 kDa (Table I, spot no. 39) and MW 21.5 kDa (Table I, spot no. 49) appeared subsequent to treatment. For CK19, there was a disappearance of spot no. 17 (Table I, MW $48 \mathrm{kDa}$ ) and an appearance of a low MW spot (Table I, spot no. 53) at $19.2 \mathrm{kDa}$ in the floating cells. S100-A6 demonstrated expression only subsequent to treatment and S100-A11 increased by four-fold subsequent to apigenin treatment.

Immunodetection of differential protein expression when treated with apigenin. Immunodetection was used to verify the presence of certain proteins from adherent and floating cells subsequent to treatment with apigenin compared with untreated cells, as demonstrated in Fig. 4. The results confirmed the disappearance of hnRNP A2/B1, hnRNP H and PTGES3 in floating cells subsequent to treatment. Upon treatment, the proteins involved in cytoskeleton/mobility function, CK7, CK8, CK18 and CK19, disappeared in the floating cells, whilst they remain unchanged in the attached cells. In contrast, S100-A6 demonstrated expression only subsequent to treatment, whereas S100-A11 expression was markedly increased subsequent to treatment, consistent with 2-DE data. The expression of S100-P was decreased in attached cells subsequent to treatment.

\section{Discussion}

Cholangiocarcinoma is a malignant tumor derived from bile duct epithelium, with high incidence in northeast Thailand (6). The proteomic and secretomic maps of HuCCA-1 cell line, a Thai human cholangiocarcinoma cell line were described by our laboratory (11). The cell line has been used for screening the cytotoxic activities of Thai medicinal plants and proteomic profiling upon treatment with pomiferin, a prenylated isoflavone from Derris malaccensis (24).

Apigenin is a promising nutraceutical, a food or part of a food that may elicit health benefits. Numerous reports of the effect of apigenin treatment on different human cancer cell lines have demonstrated an inhibition of cell growth via apoptosis and cell cycle arrest $(25,26)$ The present study investigated the effect of apigenin on a Thai cholangiocarcinoma HuCCA-1 cell line. Dose response curves after 24,48 and $72 \mathrm{~h}$ of treatment revealed inhibitory concentrations at $\mathrm{IC}_{50}$ of apigenin for HuCCA-1 cells to be 220, 75 and $68 \mu \mathrm{M}$ at 24, 48 and $72 \mathrm{~h}$, respectively. Since marked changes of morphology were observed in treated cells at $200 \mu \mathrm{M}$ apigenin, 90\% inhibition, $\mathrm{IC}_{90}$, subsequent to a 48-h incubation, this treatment condition was used for additional study.

Apoptosis, or programmed cell death, leads to DNA fragmentation, cytoskeletal reorganization, plasma membrane blebbing, nuclear condensation and loss of cell adhesion. Induction of apoptosis by apigenin in HuCCA-1 cells was demonstrated by flow cytometric analysis and confirmed by DNA fragmentation assays. The cleavage of chromosomal DNA by cellular nucleases into oligonucleosomal size fragments is a characteristic feature of apoptosis. Agarose gel electrophoresis demonstrated that the DNA ladder pattern, indicating DNA fragmentation, was identified only with floating cells and not with attached cells. This confirms that the later stages of apoptosis are exhibited in HuCCA-1 cells treated with apigenin. Typically, apoptosis occurs through the activation of specific caspases including caspase-3 (27), leading to cleavage of CK18, as demonstrated in the present study by proteomics and confirmed by western blot, consistent with previous studies (28-30). In parallel with CK18 cleavage, active caspase- 3 also cleaves an inhibitor of cellular nuclease, DNA Fragmentation Factor, allowing the active nuclease move to the nucleus and induces DNA fragmentation during apoptosis (31).

In the present study, the treatment of HuCCA-1 cells with apigenin demonstrated various types of protein alterations, namely changes in protein expression and/or cleavage. The proteins with roles in cytoskeleton/mobility revealed cleavage, and therefore this supports the presence of caspase activities during apoptosis.

The results of the present study revealed that subsequent to treatment with apigenin, the expression of S100-A6 and S100-A11 was higher in floating cells compared with attached HuCCA-1 cells during apoptosis. These two proteins are members of the $\mathrm{S} 100$ protein family and have been revealed to serve important roles in a number of tumorigenic processes, including apoptosis, cell differentiation, cell growth and cell cycle. The upregulation of S100-A6 has been demonstrated to enhance apoptosis and decrease cell viability by affecting caspase-3 activity in hepatocellular carcinoma cells (32). S100-A11 was identified to be involved in cell differentiation, cell cycle, cell growth and cell apoptosis processes. There is also evidence that S100-A11 induced cell apoptosis by involving certain parts of the translocation of apoptosis-inducing factor from the cytoplasm to nuclei (33). The expression of S100-P was also detected in HuCCA-1 cells. The S100-P has been demonstrated to serve many roles including tumorigenesis, proliferation, apoptosis and metastasis in numerous types of cancer including cholangiocarcinoma (34-36). The level of S100-P in floating apoptotic cells remains unchanged subsequent to the apigenin treatment but the expression was decreased in the attached cells, compared with control. These results suggest that, in addition to apoptosis induction, apigenin may also decrease the aggressiveness of non-apoptotic cancer cells. 
Proteins involved in protein synthesis and degradation demonstrated low or no expression subsequent to apigenin treatment, including $26 \mathrm{~S}$ protease regulatory subunit $10 \mathrm{~B}$, hnRNP H and hnRNP A2/B1. In particular, the 26S protease regulatory subunit $10 \mathrm{~B}$ is a protein associated with apoptosis, and disappears in the floating cells. The decreased activity of the $26 \mathrm{~S}$ proteasome and induction of cell death was observed only in breast cancer cells and not in normal cells, treated with Murraya koenigii leaf extract (37). The western blot of the present study also demonstrated that expression of hnRNP $\mathrm{H}$ and hnRNP A2/B1 disappeared completely subsequent to apigenin treatment. HnRNP proteins are multifunctional, participating in several cellular processes and composed of at least 20 major, high abundant or core hnRNP proteins including A1, A2/B1, B2, C1 and C2 (38). HnRNP A2/B1 has been demonstrated to be involved in splicing, mRNA stability and mRNA transport during the progress of tumorigenesis (39). Apigenin has been identified to bind specifically to the C-terminal glycine-rich domain of hnRNP A2, which is suggested to prevent hnRNP A2 from forming homodimers, resulting in alternative splicing of a number of human hnRNP A2 targets (40). HnRNP H and hnRNP C1/C2 are also involved in controlling numerous splicing decisions. The lower expression levels of hnRNP proteins upon treatment with apigenin may lead to the elimination of the splicing forms which inhibit cell death and promotion of the normal splice forms in the cells.

Chaperone/stress response proteins including prostaglandin E synthase 3, hypoxia upregulated protein 1 and $60 \mathrm{kDa}$ heat shock protein, were revealed to be downregulated subsequent to treatment with apigenin. However, stress-induced-phosphoprotein 1 was upregulated. Molecular chaperones are involved in protein folding, transport and assembly (41) and function to maintain cell survival. Elevated expression levels of heat shock proteins may promote cancer and may lead to resistance to chemotherapy and hyperthermia (42). It has been suggested that heat shock proteins and their co-chaperones are involved in the regulation of apoptosis by caspase activation (43). Stress-induced-phosphoprotein 1 (STIP1) is an Hsp70/Hsp90-organizing protein, a co-chaperone that regulates the different functions of Hsps. STIP1 has been associated with several types of cancer (44-47). PTGES3 or cytosolic prostaglandin E synthase is a $23 \mathrm{kDa}$ glutathione-requiring enzyme expressed in a wide variety of cells. It is identical to co-chaperone p23 that binds to heat shock protein 90 (Hsp90) (48). PTGES3/p23 inhibited ATPase activity to stabilize the closed conformation of Hsp90. An increased expression of PTGES3/p23 has been demonstrated to be involved in tumor progression and a poor prognosis in breast cancer (49). Additionally, in acute myelogenous leukemia, PTGES3/p23 was demonstrated to be the target for caspase in chemotherapy-induced apoptosis. The $17 \mathrm{kDa}$ product from the cleavage of PTGES3/p23 by caspase is stable in the apoptotic cells leading to chaperone activity of PTGES3/p23 (50). The results from the present study indicate that PTGES3/p23 is downregulated subsequent to treatment with apigenin, so this protein may participate in the HuCCA-1 cellular apoptosis induced by apigenin.

In conclusion, apigenin, a nutraceutical present in several vegetables and fruits, demonstrated the cytotoxic effect toward HuCCA-1. Apoptotic cell death was detected using two different methods, a flow cytometric analysis (Muse Cell Analyzer) with Annexin-V and dead cell assay kit, and DNA fragmentation confirmed the occurrence of early and late apoptosis. The proteins most significantly altered subsequent to treatment with apigenin were associated with apoptosis. The cleavage of cytokeratin 8,18 and 19 and the high expression of S100-A6 and S100-A11 indicate that apoptosis was induced by apigenin via a caspase-dependent pathway. A marked reduction in the expression of hnRNP A2/B1 was also observed, possibly with changes of splicing forms, since it has been identified that the binding of apigenin to hnRNP A2/B1 resulted in changes of the splicing forms. The present study aimed to contribute to the understanding of the usefulness of dietary flavonoids such as apigenin.

\section{Acknowledgements}

The present study was supported by the Chulabhorn Research Institute (grant no. BC 2008-02).

\section{References}

1. Kalra EK: Nutraceutical-definition and introduction. AAPS PharmSci 5: E25, 2003.

2. Manach C, Scalbert A, Morand C, Rémésy C and Jiménez L: Polyphenols: Food sources and bioavailability. Am J Clin Nutr 79: 727-747, 2004.

3. Birt DF, Walker B, Tibbels MG and Bresnick E: Anti-mutagenesis and anti-promotion by apigenin, robinetin and indole-3-carbinol. Carcinogenesis 7: 959-963, 1986.

4. Shukla S and Gupta S: Apigenin: A promising molecule for cancer prevention. Pharm Res 27: 962-978, 2010.

5. Khan SA, Toledano MB and Taylor-Robinson SD: Epidemiology, risk factors, and pathogenesis of cholangiocarcinoma. HPB (Oxford) 10: 77-82, 2008

6. Sonakul D, Koompirochana C, Chinda K and Stitnimakarn T: Hepatic carcinoma with opisthorchiasis. Southeast Asian J Trop Med Public Health 9: 215-219, 1978.

7. Kobayashi M, Ikeda K, Saitoh S, Suzuki F, Tsubota A, Suzuki Y, Arase Y, Murashima N, Chayama K and Kumada H: Incidence of primary cholangiocellular carcinoma of the liver in japanese patients with hepatitis $\mathrm{C}$ virus-related cirrhosis. Cancer 88 : 2471-2477, 2000.

8. Yamamoto S, Kubo S, Hai S, Uenishi T, Yamamoto T, Shuto T, Takemura S, Tanaka H, Yamazaki O, Hirohashi K and Tanaka T: Hepatitis $\mathrm{C}$ virus infection as a likely etiology of intrahepatic cholangiocarcinoma. Cancer Sci 95: 592-595, 2004.

9. Shaib YH, El-Serag HB, Davila JA, Morgan R and McGlynn KA: Risk factors of intrahepatic cholangiocarcinoma in the United States: A case-control study. Gastroenterology 128: 620-626, 2005.

10. Sorensen HT, Friis S, Olsen JH, Thulstrup AM, Mellemkjaer L, Linet M, Trichopoulos D, Vilstrup H and Olsen J: Risk of liver and other types of cancer in patients with cirrhosis: A nationwide cohort study in Denmark. Hepatology 28: 921-925, 1998.

11. Srisomsap C, Sawangareetrakul P, Subhasitanont P, Panichakul T, Keeratichamroen S, Lirdprapamongkol K, Chokchaichamnankit D, Sirisinha S and Svasti J: Proteomic analysis of cholangiocarcinoma cell line. Proteomics 4: 1135-1144, 2004.

12. Srisomsap C, Subhasitanont $P$, Sawangareetrakul $P$, Chokchaichamnankit D, Ngiwsara L, Chiablaem K and Svasti J: Comparison of membrane-associated proteins in human cholangiocarcinoma and hepatocellular carcinoma cell lines. Proteomics Clin Appl 1: 89-106, 2007.

13. Elmore S: Apoptosis: A review of programmed cell death. Toxicol Pathol 35: 495-516, 2007.

14. Martin SJ and Green DR: Protease activation during apoptosis: Death by a thousand cuts? Cell 82: 349-352, 1995.

15. Thornberry NA and Lazebnik Y: Caspases: Enemies within. Science 281: 1312-1316, 1998. 
16. Jaattela M: Escaping cell death: Survival proteins in cancer. Exp Cell Res 248: 30-43, 1999.

17. Levy-Strumpf $\mathrm{N}$ and Kimchi A: Death associated proteins (DAPs): From gene identification to the analysis of their apoptotic and tumor suppressive functions. Oncogene 17: 3331-3340, 1998.

18. Brockstedt E, Rickers A, Kostka S, Laubersheimer A, Dörken B, Wittmann-Liebold B, Bommert K and Otto A: Identification of apoptosis-associated proteins in a human Burkitt lymphoma cell line. Cleavage of heterogeneous nuclear ribonucleoprotein A1 by caspase 3. J Biol Chem 273: 28057-28064, 1998.

19. Prasad SC, Soldatenkov VA, Kuettel MR, Thraves PJ, Zou X and Dritschilo A: Protein changes associated with ionizing radiation-induced apoptosis in human prostate epithelial tumor cells. Electrophoresis 20: 1065-1074, 1999.

20. Gupta S, Afaq F and Mukhtar H: Selective growth-inhibitory, cell-cycle deregulatory and apoptotic response of apigenin in normal versus human prostate carcinoma cells. Biochem Biophys Res Commun 287: 914-920, 2001.

21. Choi EJ and Kim GH: Apigenin induces apoptosis through a mitochondria/caspase-pathway in human breast cancer MDA-MB-453 cells. J Clin Biochem Nutr 44: 260-265, 2009.

22. Xu Y, Xin Y, Diao Y, Lu C, Fu J, Luo L and Yin Z: Synergistic effects of apigenin and paclitaxel on apoptosis of cancer cells. PLoS One 6: e29169, 2011.

23. Khan A, Gillis K, Clor J and Tyagarajan K: Simplified evaluation of apoptosis using the Muse cell analyzer. Postepy Biochem 58: 492-496, 2012

24. Svasti J, Srisomsap C, Subhasitanont P, Keeratichamroen S, Chokchaichamnankit D, Ngiwsara L, Chimnoi N, Pisutjaroenpong S, Techasakul S and Chen ST: Proteomic profiling of cholangiocarcinoma cell line treated with pomiferin from Derris malaccensis. Proteomics 5: 4504-4509, 2005.

25. Ruela-de-Sousa RR, Fuhler GM, Blom N, Ferreira CV, Aoyama H and Peppelenbosch MP: Cytotoxicity of apigenin on leukemia cell lines: Implications for prevention and therapy. Cell Death Dis 1: e19, 2010.

26. Vargo MA, Voss OH, Poustka F, Cardounel AJ, Grotewold E and Doseff AI: Apigenin-induced-apoptosis is mediated by the activation of PKCdelta and caspases in leukemia cells. Biochem Pharmacol 72: 681-692, 2006.

27. Creagh EM, Conroy H and Martin SJ: Caspase-activation pathways in apoptosis and immunity. Immunol Rev 193: 10-21, 2003.

28. Caulin C, Salvesen GS and Oshima RG: Caspase cleavage of keratin 18 and reorganization of intermediate filaments during epithelial cell apoptosis. J Cell Biol 138: 1379-1394, 1997.

29. Leers MP, Kolgen W, Björklund V, Bergman T, Tribbick G, Persson B, Björklund P, Ramaekers FC, Björklund B, Nap M, et al: Immunocytochemical detection and mapping of a cytokeratin 18 neo-epitope exposed during early apoptosis. J Pathol 187: 567-572, 1999.

30. Schutte B, Henfling M, Kölgen W, Bouman M, Meex S, Leers MP, Nap M, Björklund V, Björklund P, Björklund B, et al: Keratin $8 / 18$ breakdown and reorganization during apoptosis. Exp Cell Res 297: 11-26, 2004.

31. Mitamura S, Ikawa H, Mizuno N, Kaziro Y and Itoh H: Cytosolic nuclease activated by caspase-3 and inhibited by DFF-45. Biochem Biophys Res Commun 243: 480-484, 1998.

32. Joo JH, Yoon SY, Kim JH, Paik SG, Min SR, Lim JS, Choe IS, Choi I and Kim JW: S100A6 (calcyclin) enhances the sensitivity to apoptosis via the upregulation of caspase-3 activity in Hep3B cells. J Cell Biochem 103: 1183-1197, 2008.

33. Makino E, Sakaguchi M, Iwatsuki K and Huh NH: Introduction of an N-terminal peptide of S100C/A11 into human cells induces apoptotic cell death. J Mol Med (Berl) 82: 612-620, 2004.

34. Hamada S, Satoh K, Hirota M, Kanno A, Ishida K, Umino J, Ito H, Kikuta K, Kume K, Masamune A, et al: Calcium-binding protein S100P is a novel diagnostic marker of cholangiocarcinoma. Cancer Sci 102: 150-156, 2011.

35. Nakanuma Y and Sato Y: Hilar cholangiocarcinoma is pathologically similar to pancreatic duct adenocarcinoma: Suggestions of similar background and development. J Hepatobiliary Pancreat Sci 21: 441-447, 2014
36. Wu Z, Boonmars T, Nagano I, Boonjaraspinyo S, Srinontong P, Ratasuwan P, Narong K, Nielsen PS and Maekawa Y: Significance of S100P as a biomarker in diagnosis, prognosis and therapy of opisthorchiasis-associated cholangiocarcinoma. Int J Cancer 138: 396-408, 2016.

37. Noolu B, Ajumeera R, Chauhan A, Nagalla B, Manchala R and Ismail A: Murraya koenigii leaf extract inhibits proteasome activity and induces cell death in breast cancer cells. BMC Complement Altern Med 13: 7, 2013

38. Beyer AL, Christensen ME, Walker BW and LeStourgeon WM: Identification and characterization of the packaging proteins of core 40S hnRNP particles. Cell 11: 127-138, 1977.

39. Cooper TA, Wan L and Dreyfuss G: RNA and disease. Cell 136: 777-793, 2009

40. Arango D, Morohashi K, Yilmaz A, Kuramochi K, Parihar A, Brahimaj B, Grotewold E and Doseff AI: Molecular basis for the action of a dietary flavonoid revealed by the comprehensive identification of apigenin human targets. Proc Natl Acad Sci USA 110: E2153-E2162, 2013.

41. Lindquist S and Craig EA: The heat-shock proteins. Annu Rev Genet 22: 631-677, 1988.

42. Calderwood SK and Ciocca DR: Heat shock proteins: Stress proteins with Janus-like properties in cancer. Int $\mathrm{J}$ Hyperthermia 24: 31-39, 2008.

43. Takayama S, Reed JC and Homma S: Heat-shock proteins as regulators of apoptosis. Oncogene 22: 9041-9047, 2003.

44. Kubota H, Yamamoto S, Itoh E, Abe Y, Nakamura A, Izumi Y, Okada H, Iida M, Nanjo H, Itoh $\mathrm{H}$ and Yamamoto Y: Increased expression of co-chaperone HOP with HSP90 and HSC70 and complex formation in human colonic carcinoma. Cell Stress Chaperones 15: 1003-1011, 2010.

45. Sun W, Xing B, Sun Y, Du X, Lu M, Hao C, Lu Z, Mi W, Wu S, Wei $\mathrm{H}$, et al: Proteome analysis of hepatocellular carcinoma by two-dimensional difference gel electrophoresis: Novel protein markers in hepatocellular carcinoma tissues. Mol Cell Proteomics 6: 1798-1808, 2007.

46. Erlich RB, Kahn SA, Lima FR, Muras AG, Martins RA, Linden R, Chiarini LB, Martins VR and Moura Neto V: STI1 promotes glioma proliferation through MAPK and PI3K pathways. Glia 55: 1690-1698, 2007.

47. Wang TH, Chao A, Tsai CL, Chang CL, Chen SH, Lee YS, Chen JK, Lin YJ, Chang PY, Wang CJ, et al: Stress-induced phosphoprotein 1 as a secreted biomarker for human ovarian cancer promotes cancer cell proliferation. Mol Cell Proteomics 9: $1873-1884,2010$

48. Tanioka T, Nakatani Y, Semmyo N, Murakami M and Kudo I: Molecular identification of cytosolic prostaglandin E2 synthase that is functionally coupled with cyclooxygenase-1 in immediate prostaglandin E2 biosynthesis. J Biol Chem 275: 32775-32782, 2000 .

49. Simpson NE, Lambert WM, Watkins R, Giashuddin S, Huang SJ, Oxelmark E, Arju R, Hochman T, Goldberg JD, Schneider RJ, et al: High levels of Hsp90 cochaperone p23 promote tumor progression and poor prognosis in breast cancer by increasing lymph node metastases and drug resistance. Cancer Res 70: 8446-8456, 2010.

50. Gausdal G, Gjertsen BT, Fladmark KE, Demol H, Vandekerckhove J and Doskeland SO: Caspase-dependent, geldanamycin-enhanced cleavage of co-chaperone p23 in leukemic apoptosis. Leukemia 18: 1989-1996, 2004. 